\title{
Study on Functional Properties of Physically Modified Dietary Fibres Derived from Defatted Rice Bran
}

\author{
Cheickna Daou ${ }^{1,2,3}$ \& Hui Zhang ${ }^{1,2}$ \\ ${ }^{1}$ State Key Laboratory of Food Science and Technology, 1800 Lihu Road, Wuxi, China \\ ${ }^{2}$ School of Food Science and Technology, Jiangnan University, 1800 Lihu Road, Wuxi, China \\ ${ }^{3}$ Universite des Science Technique et technologique de Bamako, Rep. Mali \\ Correspondence: Hui Zhang, State Key Laboratory of the School of Food Science and Technology, Jiangnan \\ University, 1800 Lihu Road, Wuxi 214122, China. E-mail: zhanghui@jiangnan.edu.cn
}

Received: May 3, 2012 Accepted: June 18, 2012 Online Published: July 26, 2012

doi:10.5539/jas.v4n9p85 URL: http://dx.doi.org/10.5539/jas.v4n9p85

\begin{abstract}
In this study, we investigated the predictive indices for hypoglycemic effect of physically modified fibers. Micronization, ultrasonic, microwave and extrusion cooking treatments were applied to defatted rice bran dietary fibers to get modified defatted rice bran dietary fiber. The effects of physical treatments, $\mathrm{pH}$ and time of digestion, on the water binding Capacity (WBC), Swelling Capacity (SWC), Cation exchange Capacity (CEC) and Glucose retardation capacity (GDRI) were studied. All modified fibers exhibited significance $(\mathrm{p} \leq 0.05)$ difference in terms of their hydration capacity at $\mathrm{pH} 8.7$ with extruded fibers showing the highest values for $\mathrm{WBC}$ and $\mathrm{SWC}(4.68 \mathrm{~g} / \mathrm{g}$ and $3.66 \mathrm{ml} / \mathrm{g}$ respectively), while micronized fiber had the lowest value of CEC at $\mathrm{pH}$ $1.8(0.15 \mathrm{meq} / \mathrm{g})$. Extruded fiber showed higher GDRI $(40.73 \%)$, thus higher glucose adsorption capacity $(4161 \mu \mathrm{mol} / \mathrm{g})$. It displayed greatest retardation effect against the movement of glucose across the dialysis bag for $9 \mathrm{~h}$ compared to other treatments.

The study showed that physically modified defatted rice bran dietary fibers have reduction effect on glucose breakdown rate and adsorption and thus can avoid increase in postprandial blood glucose level Therefore, these physically modified fibres showed important improved physiological effects (hypoglycemic effect) and can be incorporated in foods to enhance health benefits.
\end{abstract}

Keywords: dietary fibre, physical treatments, functional properties, hypoglycemic effect

\section{Introduction}

Dietary fiber refers to the edible part of plants or corresponding carbohydrates that are resistant to digestion in the small intestines, but undergoes complete or incomplete fermentation in the large intestines. Polysaccharides, oligosaccharides, and associated plant substances are examples of dietary fibers. This group of carbohydrates is associated with a number of positive physiological effects such as laxation, blood cholesterol and glucose lowering (Dietary Reference Intakes Proposed Definition of Dietary Fiber, 2001).

The significance of dietary fiber of late is gaining increase acceptance due to its potential beneficial influence including control of gastrointestinal (GI) disorders, diabetes, obesity and cardiovascular diseases. However, such disorders have a very low incidence among people consuming recommended amount (25-30g/day) of fiber (Sreenath, Katsambis, Sudarshanakrishna, Prasad, \& Santhanam, 1996; Sangnark \& Noomhorm, 2004). Total dietary fibre (TDF) is a chemical complex having the ability to react and interact within food structure and human digestive system (Valiente, Molla, Martin-Cabrejas, Lopez-Andreu, \& Esteban, 1996). It can exert its influence on the gut directly and also possess indirect metabolic actions which alter the outline of digestion and absorption (Schneeman, 1998).

Because of its viscosity and solubility, TDF (containing soluble and insoluble dietary fibre) is able to lower blood cholesterol and triacylglyceride concentrations as well as attenuate the post-prandial glucose response; likewise because of its physical characteristics and capability to increase fecal bulking and reduce intestinal transit time and thus improves intestinal peristalsis (Fleury \& Lahaye, 1991; Gupta \& Premavalli, 2011). The dietary fibre content, the chemical composition of fibre, and the physical state of fibre are also important. Micronization including super milling, ball milling, jet milling and high pressure micronization increases 
bioavailability of digestible carbohydrates In-vitro and In-vivo (O’Dea, Nestel, \& Antonoff, 1980) and efficiently minimizes size particles to boost the functionality of the fiber (Chau, Wang, \& Wen, 2007). Reduction of particle sizes via the treatment of micronization could greatly change the surface area and functional properties of tested samples, thereby allowing innovative applications of these materials in the food development and biological or material sciences (Ogawa, Decker, \& Clements, 2003). Extrusion cooking that involves heating in combination with homogenization is expected to affect dietary fibre in term of both physiological properties and fibre analyses. Thus, extrusion cooked wheat bran was no less beneficial to glucose excretion in alloxandiabetic rats compared with raw bran (Varo Laine, \& Koivistoinen, 1983). In the extruder, the material is subjected to intense mechanical shear and cooking occurs at high temperature, pressure and low water content. The mechanical treatment completely disorganizes the original structure of material. The new structure obtained is referred to as "uniform plasticized dough" (Björck, Nyman, \& ASP, 1984). On the other hand, several changes in physical parameters as well as chemical constituents of vegetables and other food matters could be realized when cooking is applied. In addition the process also can exert some structural changes in dietary fibers obtained from various sources (Özlem, 2009). Some studies have demonstrated that microwaves, a nonionising energy that can generate heat deep inside the penetrated medium by the "molecular friction" in an alternating electromagnetic field (Lewandowicz, Formal, \& Walkowski, 1997) are able to alter the structure of lignocellulosic matters to permit disintegration of the lignin and hemicelluloses and eventually change the ultra structure of cellulose and promote the enzymatic hydrolysis of biomass materials (Shengdong, et al., 2005; Zhu et al., 2006). While ultrasonic treatment can be generated internally in the material a strong vibration, high acceleration and powerful cavitation that can damage the plant cells, decrease plant tissue between each component in the close degree of integration and cause the bond breaking (Chen, Yang, \& Xu, 2001) thus, sonication can be applied to disrupt the (1 4)- $\beta$-linkage (depolymerization) and promote the deacetylation of chitinous materials including those of dietary fiber. The theory underlining the above physical means is to provide the added energy required to break the chemical bonds (Chen, Chang, \& Shyur, 1997). All of these physical treatments cause structural and Physico-chemical changes in the dietary fibre which could be related with its functional properties.

The main objective of this study was to investigate the effects of micronization, ultrasonic, microwave and extrusion cooking treatments (physical treatments) on physical properties such as particle sizes, solubility and viscosity, and also on the major functional properties (WBC, SWC, CEC and GDRI) of the defatted rice bran dietary fibre under the simulated condition of $\mathrm{pH}$ and time of passage in human system. The behaviors of these physically modified fibers in the human digestive tract through their glucose adsorption and diffusion capacity were also studied.

\section{Materials and Methods}

\subsection{Materials}

Defatted rice bran was obtained from Oil Company located in Xuzhou (Jiangsu Province China) with 2.8\% fat remain in the bran.

Termamyl (heat stable $\alpha$-amylase $20.000 \mathrm{U} / \mathrm{g}$-Novozymes Biological Engineering - Beijing - China), Alcalase (Alcalase 2.4L (2.4 AU/g) Novozymes Biological Engineering Beijing- China), amyloglucosidase (100.000U/g Novozymes Biological Engineering Beijing - China) were the used enzymes. All other chemical used were of analytical grade.

\subsection{Preparation of Defatted Rice Bran Dietary Fiber (DRBDF)}

Total dietary fiber was extracted according to the method described by Mirko et al. (2003) with some modifications. The defatted rice bran was cooked with termamyl $(75 \mu \mathrm{L} / \mathrm{g})$ at $100^{\circ} \mathrm{C}$ for $1 \mathrm{~h}$ to give gelatinisation, hydrolysis and depolymerisation of starch. After termamyl treatment the sample was digested with alcalase $(35 \mu \mathrm{L} / \mathrm{g})$ at $60^{\circ} \mathrm{C}$ for $1 \mathrm{~h}$ to solubilise and depolymerise proteins. Enzymatic treatment was completed with incubation with amyloglucosidase $(30 \mu \mathrm{L} / \mathrm{g})$ at $60^{\circ} \mathrm{C}$ for 1 hour to hydrolyse starch fragments to glucose. After these treatments, the sample was suspended in four volumes of $80 \%$ ethanol (preheated at $60^{\circ} \mathrm{C}$ ) to precipitate DRBDF and remove depolymerised protein and glucose. The precipitate was allowed to form at room temperature for $1 \mathrm{~h}$, followed by centrifugation at $4000 \mathrm{rpm}$ for $15 \mathrm{~min}$. The residue was washed twice with $78 \%$ ethanol, $95 \%$ ethanol and acetone respectively, and was dried in a vacuum oven at $60^{\circ} \mathrm{C}$. After that, DRBDF were stored at $0-4^{\circ} \mathrm{C}$ for further use.

\subsection{Physical Modification of DRBDF}

The obtained DRBDF was grounded in a flour mill and then passed through sieve $(0.8 \mathrm{~mm})$. The DRBDF was modified by using the following physical treatments: 
> Micronization was carried out using Ultra-fine powder machine (MZF-4L). DRBDF sample was grounded for $1 \mathrm{~h}$ to reduce a particle size and then kept samples at $0-4^{\circ} \mathrm{C}$ for further analysis.

$>$ Ultrasonic treatment was carried out as follows: the mixture of DRBDF and water at the ratio 1:12 (w/v) were placed in glass flask and subjected to ultrasonic treatment. Sonicator JY98-3D (Ningbo Scientz. Biotechnology Co. LTD) was used at frequency of $25 \mathrm{KHz}$, power $100 \mathrm{~W}$ for $1 \mathrm{~h}$ at room temperature $\left(25^{\circ} \mathrm{C}\right)$. After treatment, the sample kept at $0-4{ }^{\circ} \mathrm{C}$.

$>$ Microwave treatment was done by heating the mixture of DRBDF and water at ratio 1:10 (w/v) in Microwave Experiment Instrument type MZG 1500S (Nanjing Huiyan Microwave System Engineering Company Limited) at power $700 \mathrm{~W}$ for $10 \mathrm{~min}$. After treatment, the sample was freeze dried and kept at $0-4{ }^{\circ} \mathrm{C}$.

$>$ Extrusion treatment of DRBDF was carried out using the twin-screw laboratory extruder Thermo HAAKE Polylab System Extruder PTW24/25D (Thermo Electron Corporation- Germany). Barrel temperature varied from feed end to die end as follow: $50-75-95-100{ }^{\circ} \mathrm{C}$. A feed rate of $0.7 \mathrm{~kg} / \mathrm{h}$ and screw speed of $90 \mathrm{rpm}$ were held constant. The initial moisture was $18 \%$ and it was equilibrated by injection water in extruder at rate of about $0.45 \mathrm{~kg} / \mathrm{h}$. Extruded DRBDF was then ground and passed through a $0.8 \mathrm{~mm}$ sieve.

\subsection{Particle Size Distribution of Physically Modified DRBDF}

The particle sizes of each modified DRBDF were estimated by laser particle size analyzer Microtrac S3500 and SDC Model Bluewave (Microtrac Inc-USA). An amount of $500 \mathrm{mg}$ of powder of each modified fibres was placed in the laser particle size analyzer for determination of its size distribution.

\subsection{Determination of Solubility and Viscosity of Physically Modified DRBDF}

\subsubsection{Solubility}

The solubility of the physically modified DRBDF samples was determined according to the method described by Chau, Wang, \& Wen (2007). Modified DRBDF samples were diluted in distilled water (1:10 w/v) and stirred for $1 \mathrm{~h}$ at room temperature. After centrifugation $(1500 \mathrm{rpm})$ for $10 \mathrm{~min}$, the supernatant and residue were collected, freeze dried and weighed.

$$
\text { Solubility }(\%)=[\text { weight }(\mathrm{g}) \text { of supernatant after freeze drying/weight }(\mathrm{g}) \text { of sample }] \times 100
$$

\subsubsection{Viscosity}

Viscosity of physically modified DRBDF samples was determined according to the method of Frost, Hegedus, \& Glicksman (1984).Samples of 4 varied concentration slurries (1,3,5 and 7\% ) were made by gradually adding the measured amount of modified DRBDF to distilled water while mixing at high speed for $1 \mathrm{~min}$ in a warring blender. In order to equilibrate the solution, each was allowed to settle at room temperature for $24 \mathrm{~h}$. The viscosity of each solution was measured upon the removal of the entrapped air. The measurement was done using a Rheometer AR-1000 (TA. Instruments) with Steel cone $2^{\circ}, 60 \mathrm{~mm}$ under the following conditions; Shear stress $(\mathrm{Pa}): 1-50$; Shear rate $\left(\mathrm{S}^{-1}\right): 0-50$; and $\mathrm{Gap}(\mu \mathrm{m}): 1000$ at room temperature.

\subsection{Water Binding and Swelling Capacity}

Water binding capacity (WBC) and swelling capacity (SWC) were investigated based on the modified methods of Gorecka, Lampart-Szczapa, Janitz, \& Sokolowska (2000) and Sowbhaya, Florence Suma, Mahadevamma, \& Taranathan (2007) respectively. The modifications were done in such as a way that the above properties were investigated under experimental $\mathrm{pH}$ conditions which may be encountered in specific part of human GIT (i.e. oral cavity: $\mathrm{pH}$ 6.6, passage time $7 \mathrm{~min}$; in the stomach: $\mathrm{pH} 1.8$ and 135 min and duodenum: $\mathrm{pH} 8.7$ and $60 \mathrm{~min}$.)

\subsubsection{Water Binding Capacity}

Water- binding capacities were determined by measuring $1 \mathrm{~g}$ of fiber sample into a plastic centrifuge tubes already followed by addition of $30 \mathrm{~mL}$ of buffers with different $\mathrm{pHs}(\mathrm{pH} \mathrm{6.6,} \mathrm{pH} 1.8$ and $\mathrm{pH} 8.7$ ) to each tube already containing the fiber sample. The tubes were held at $37{ }^{\circ} \mathrm{C}$ in the water bath and shaken for $7 \mathrm{~min}, 135 \mathrm{~min}$ and $60 \mathrm{~min}$ for tubes with samples containing buffers with $\mathrm{pH} 6.6, \mathrm{pH} 1.8$ and $\mathrm{pH} 8.7$ respectively. The tubes with the soaked fiber were subjected to centrifugation ( $3000 \mathrm{~g}$ for $15 \mathrm{~min}$ ) and supernatant removed carefully. The tubes were slanted for $30 \mathrm{~min}$ to drain off the excess water. The wet mass in each tube was removed, weighed, and dried to constant weight $( \pm 0.05 \mathrm{mg})$ at $100^{\circ} \mathrm{C}$. The data obtained was expressed as gram of water bound per gram of dry initial sample.

\subsubsection{Swelling Capacity}

Three swelling capacities were also determined by weighing $1 \mathrm{~g}$ of fiber into graduated glass cylinder and the initial volume occupied by the fiber recorded. Thereafter, $30 \mathrm{ml}$ of different buffers were added to maintain the 
$\mathrm{pH}$ at 6.6, 1.8 and 8.7, and the samples were allowed to swell for $7 \mathrm{~min}, 135 \mathrm{~min}$ and $60 \mathrm{~min}$ respectively. The final volumes were noted and expressed as $\mathrm{ml}$ of swollen sample per gram of dry initial sample.

\subsection{Cation Exchange Capacity (CEC)}

Cation exchange capacity was also determined as described by Gorecka, Lampart-Szczapa, Janitz, \& Sokolowska (2000) under the same conditions as WBC. Three varied cation exchange capacities were investigated by treating the fiber samples with excess $2 \mathrm{M} \mathrm{HCl}$ for 48 hours to convert the fiber matter into. This was followed by filtration before $100 \mathrm{ml}$ of $5 \% \mathrm{NaCl}$ in buffers $(\mathrm{pH} 6.6, \mathrm{pH} 1.8$, and $\mathrm{pH} 8.7)$ was added to $0.5 \mathrm{~g}$ of each wet fiber residue. The samples were incubated and shaken at $37^{\circ} \mathrm{C}$ for $7 \mathrm{~min}, 135 \mathrm{~min}$ and $60 \mathrm{~min}$ and the solutions titrated with $\mathrm{NaOH} / \mathrm{HCl}$. The results were expressed as meq per gram dry initial sample.

\subsection{Glucose Dialysis Retardation Index (GDRI)}

The GDRI was measured according to the procedure reported by Adiotomre, Eastwood, Edwards, \& Brydon, (1990). The effect of fiber on jejunal nutrient absorption was indicated by the glucose dialysis retardation index, which is calculated as:

GDRI $=$ [100-[total glucose diffused from sac containing fiber/total glucose diffused from control] x100]

Ten-centimeter lengths of dialysis bags (12000 - 14000 MWCO, Dialysis Tubing Visking, Medicell International Ltd, London, UK) were soaked in $1 \mathrm{~g}$ sodium azide/L the bag was filled with $6 \mathrm{ml}$ of sodium azide solution, $36 \mathrm{mg}$ glucose and $0.2 \mathrm{~g}$ of fiber. The control was made by mixture of sodium azide solution and glucose. Fiber had been hydrated in an aqueous solution of $1 \mathrm{~g}$ sodium azide/ $\mathrm{L}$ for 14 hours before dialysis. The bag tied and suspended in $100 \mathrm{ml}$ of $1 \mathrm{~g}$ sodium azide/L and placed in stirred bath at $37^{\circ} \mathrm{C}$ for $60 \mathrm{~min}$. At 30 and $60 \mathrm{~min}, 2 \mathrm{ml}$ were taken from the dialysate and were analyzed for glucose by the glucose oxidase- peroxidase method.

\subsection{Glucose Diffusion Assay}

Glucose diffusion assay was done based on the method revealed by Ou, Kwok, Li, \& Fu (2001) with minimal adjustment. Briefly, $0.5 \mathrm{~g}$ of modified fiber sample was efficiently mixed in $25 \mathrm{~mL}$ of glucose solution $(100 \mathrm{mM} / \mathrm{L})$. The mixture was then dialyzed against $200 \mathrm{~mL}$ deionized water $(\mathrm{pH} 7.0)$ in a thermostatically controlled orbital shaker maintained at $37^{\circ} \mathrm{C}$ for 24 hours with gently shaking for $3 \mathrm{~h}$ to mimic intestinal peristalsis, followed by $3 \mathrm{~h}$ without shaking. The incubation without shaking was allowed for $12 \mathrm{~h}$. The dialysis membrane used had a cutoff molecular weight of $12.000 \mathrm{Da}$. The amount of glucose in the dialysate was measured at regular time intervals of $3 \mathrm{~h}$ for the first half of total incubation period using a glucose oxidase-peroxidase method by spectrophotometric means. At the end of $24 \mathrm{~h}$, the glucose content in the dialysate was again measured. A control test was carried out without addition of fibre.

\subsection{Determination of Glucose Adsorption Capacity}

Glucose adsorption capacity was determined according to the method described by Ou, Kwok, Li, \& Fu (2001). One gram sample was mixed with $100 \mathrm{ml}$ of glucose solution $(50 \mathrm{mM} / \mathrm{L})$ and incubated at $37^{\circ} \mathrm{C}$ for 6 hours. After centrifugation at $4000 \mathrm{~g}$ for $20 \mathrm{~min}$. the glucose content in the supernatant was measured using the DNS colorimetry method to estimate the amount of glucose adsorbed by the fiber sample.

\subsection{Statistical Analysis}

Each measurement was done in triplicate and means and standard deviation (SD) computed. The results were the expressed as mean $\pm \mathrm{SD}$. Data were statistically evaluated by one-way analysis of variance (ANOVA) by adopting SPSS (version 17) for significance $(\mathrm{p} \leq 0.05)$ and the Tukey test at $95 \%$ confidence level.

\section{Results and Discussion}

\subsection{Particle Size Distribution of Physically Modified DRBDF}

The effects of physical treatments on particle size of DRBDF are shown in the Table 1 . Considering $50 \%$ of the volume of untreated and treated DRBDF, micronization greatly reduced particle size of fibers to $(24 \mu \mathrm{m})$ followed by Microwave treatment $(58 \mu \mathrm{m})$, ultrasonic treatment $(61 \mu \mathrm{m})$ and extrusion treatment $(87 \mu \mathrm{m})$. Untreated DRBDF showed the highest particle size $(133 \mu \mathrm{m})$. However, ultrasonic treated DRBDF showed smallest particles $(195 \mu \mathrm{m})$ followed by micronization $(403 \mu \mathrm{m})$, and microwave $(475 \mu \mathrm{m})$ when $95 \%$ of volume of treated and untreated DRBDF were measured. While untreated and extruded DRBDF had almost the same size (685 vs. 700 respectively). 
Table 1. Particle sizes distribution of PMDF

\begin{tabular}{cccccccc}
\hline Type of treatments & Percentile of samples & \multicolumn{4}{c}{ Sizes (Um) } & Averages \\
\hline \multirow{3}{*}{ Untreated } & $50 \%$ & 35.97 & 83.14 & 369.9 & 165.1 & 67.98 & 133.79 \\
& $95 \%$ & 190.5 & 209.5 & 1499 & 1711 & 297 & 685.57 \\
Micronization & $50 \%$ & 21.57 & 20.87 & 28.37 & 31.81 & 22.06 & 24.73 \\
& $95 \%$ & 77.86 & 88.44 & 856 & 555 & 257 & 403.27 \\
Ultrasonic & $50 \%$ & 62.84 & 62.48 & 58.42 & 61.54 & 62.16 & 61.93 \\
& $95 \%$ & 198.4 & 188.1 & 188.7 & 190 & 183.1 & 195.08 \\
Microwave & $50 \%$ & 53.08 & 49.34 & 55.66 & 64.54 & 78.34 & 58.16 \\
& $95 \%$ & 198.5 & 217.2 & 438.6 & 724.1 & 1042 & 475.48 \\
Extrusion & $50 \%$ & 81.86 & 57.54 & 120 & 120.3 & 81.74 & 87.62 \\
& $95 \%$ & 1337 & 334.1 & 1030 & 1065 & 209 & 700.27 \\
\hline
\end{tabular}

\subsection{Solubility and Viscosity of Physically Modified DRBDF}

The solubility of physically modified DRBDF was significantly $(\mathrm{p}<0.05)$ higher than that of untreated DRBDF. Micronized DRBDF showed the highest solubility $(8.31 \pm 0.91 \%)$ followed by microwaved $(8.03 \pm 0.18 \%)$, Ultrasonicated (7.95 $\pm 0.06 \%)$ and extruded $(6.80 \pm 0.73 \mathrm{~b} \%)$. Untreated DRBDF, compared to modified, showed the lowest solubility $(5.95 \pm 0.13 \%)$. This solubility of micronized DRBDF was lower than that of Mangifera pajang fiber (Sadeq et al., 2011) but higher than various micronized fractions of water caltrop pericarp (Chiun, Jhih-Ying, \& Po-Yuan, 2009). The solubilities of treated DRBDF were significantly different $(\mathrm{p}<0.05)$ from each other and it increased proportionally as the particle sizes decreased.

Thus, micronization treatment significantly reduces the particle size and micronized DRBDF exhibited significantly $(\mathrm{p}<0.05)$ higher solubility compared to other treatments.

According to Figure 1, the physically modified DRBDF as well as untreated DRBDF showed a low viscosity at all concentrations. However extruded DRBDF solution $(7 \% \mathrm{w} / \mathrm{v})$ showed a higher viscosity $(27.24 \mathrm{mPa}$.s. $)$ at shear rate $5 \mathrm{~s}^{-1}$. The lowest viscosity of modified DRBDF solutions might be explained by their high content of insoluble fibers which were dispersed and become swollen rapidly in water without gel formation or by their small particle sizes of these DRBDF. Large particle sizes of fibers could obviously increase the viscosity of suspension while the small particle sizes produced very low viscosity (Prakongpan, Nitithamyong, \& Luangpituksa, 2002).

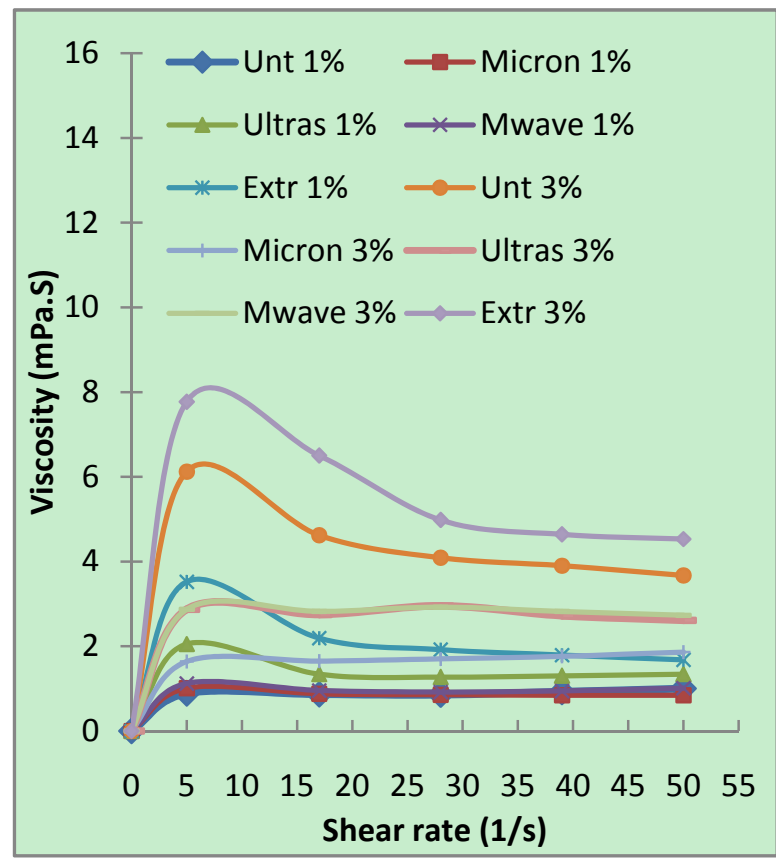

a

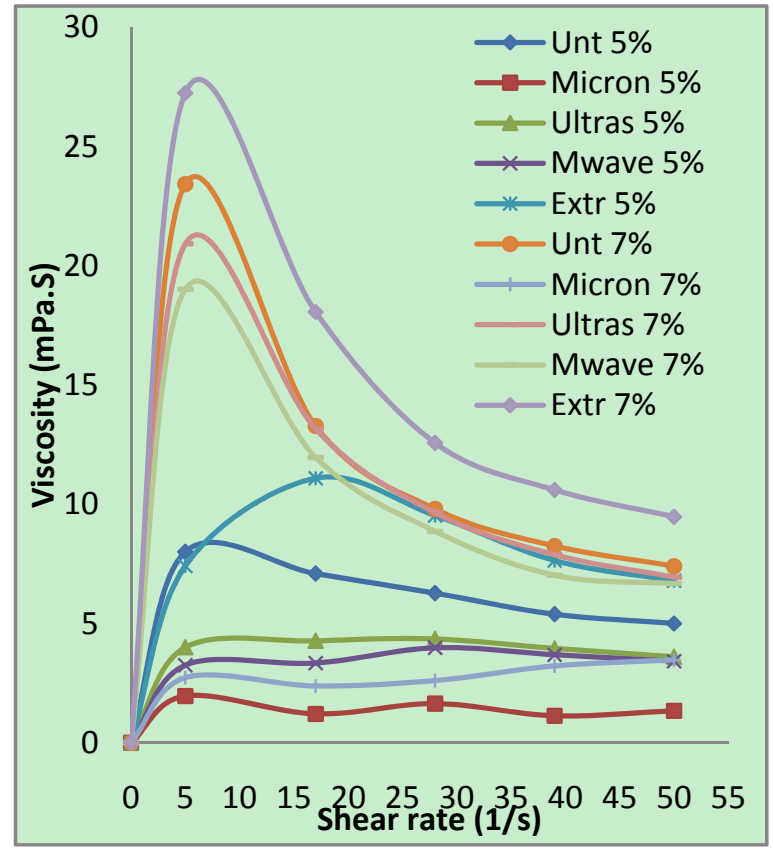

$\mathrm{b}$

Figure 1. Viscosity of PMDF with different concentrations at different shear rates of physical modify dietary fibres (PMDF) derived from defatted rice bran 
Extruded and untreated DRBDF at all concentration showed the highest viscosity compared to others treated DRBDF. The high viscosity may be due to their relatively large particle sizes as well structural and physico-chemical changes cause for extrusion. However, the viscosity of all DRBDF solutions at low concentrations were similar or lower than those reported by Ang (1991) for powdered cellulose and greater than themselves at high concentration of DRBDF solutions.

The viscosity of fiber suspensions depends also on molecular shape, size and charges (Branen, Davidson, \& Salminen, 1990). Generally, long linear molecules have greater resistance to shear than short or branched molecules.

\subsection{Effect of Physical Treatments and pH on Water Binding Capacity (WBC) and Swelling Capacity (SWC)}

WBC is a useful parameter because it serves as index for predicting the fecal bulking ability of a fiber material. It is also closed associated with fiber structure, particle size and the number of its water binding sites (Chau \& Huang, 2004). On the other hand, WBC is more a function of fiber structure than chemical composition (Robertson \& Eastwood, 1981).The results of WBC of the modified DRBDF are shown in Table 2.

Table 2. Hydration properties and Cation exchange capacity of PMDF under stimulate conditions of digestive tract

\begin{tabular}{|c|c|c|c|c|}
\hline \multirow[b]{2}{*}{ Properties } & \multirow[b]{2}{*}{ Treatments } & \multicolumn{3}{|c|}{$\mathrm{pH}$ and incubation time } \\
\hline & & $\begin{array}{l}\text { Oral cavity } \\
(\mathrm{pH} \quad 6.6) \\
\text { incubation } \\
\text { time } 7 \mathrm{mmin}\end{array}$ & $\begin{array}{l}\text { Stomach } \\
(\mathrm{pH} \quad 1.8) \\
\text { incubation } \\
\text { time } 135 \\
\text { min }\end{array}$ & $\begin{array}{l}\text { Duodenum } \\
(\mathrm{pH} \quad 8.7) \\
\text { incubation } \\
\text { time } 60 \mathrm{~min}\end{array}$ \\
\hline \multirow{5}{*}{$\begin{array}{l}\text { Water } \\
\text { Binding } \\
\text { Capacity, } \\
\mathrm{g} / \mathrm{g}\end{array}$} & Unt & $3.18 \pm 0.01 b c$ & $2.99 \pm 0.03 b$ & $4.50 \pm 0.13 b$ \\
\hline & Micro & $2.68 \pm 0.09 \mathrm{a}$ & $2.56 \pm 0.28 \mathrm{a}$ & $3.74 \pm 0.11 \mathrm{a}$ \\
\hline & Ultras & $2.83 \pm 0.15 \mathrm{ab}$ & $3.90 \pm 0.08 \mathrm{c}$ & $4.46 \pm 0.09 \mathrm{~b}$ \\
\hline & Mwave & $4.78 \pm 0.03 d$ & $2.56 \pm 0.10 \mathrm{a}$ & $4.76 \pm 0.14 \mathrm{~cd}$ \\
\hline & Extrusion & $3.29 \pm 0.07 \mathrm{c}$ & $2.60 \pm 0.03 \mathrm{a}$ & $4.68 \pm 0.01 \mathrm{c}$ \\
\hline \multirow{5}{*}{$\begin{array}{l}\text { Swelling } \\
\text { capacity, } \\
\mathrm{ml} / \mathrm{g}\end{array}$} & Unt & $2.64 \pm 0.05 b$ & $1.95 \pm 0.01 b c$ & $3.49 \pm 0.01 \mathrm{c}$ \\
\hline & Micro & $2.01 \pm 0.13 \mathrm{a}$ & $1.77 \pm 0.03 b$ & $2.92 \pm 0.07 \mathrm{~b}$ \\
\hline & Ultras & $2.08 \pm 0.04 \mathrm{a}$ & $1.36 \pm 0.03 \mathrm{a}$ & $2.02 \pm 0.02 \mathrm{a}$ \\
\hline & Mwave & $1.85 \pm 0.14 \mathrm{a}$ & $1.36 \pm 0.12 \mathrm{a}$ & $2.85 \pm 0.07 \mathrm{~b}$ \\
\hline & Extrusion & $2.51 \pm 0.20 \mathrm{~b}$ & $2.09 \pm 0.27 \mathrm{c}$ & $3.66 \pm 0.07 \mathrm{c}$ \\
\hline \multirow{5}{*}{$\begin{array}{l}\text { Cation } \\
\text { Exchange } \\
\text { capacity, } \\
\text { meq/g }\end{array}$} & Unt & $1.17 \pm 0.08 \mathrm{ab}$ & $0.30 \pm 0.09 \mathrm{~b}$ & $1.20 \pm 0.10 \mathrm{~b}$ \\
\hline & Micro & $1.10 \pm 0.07 \mathrm{ab}$ & $0.15 \pm 0.03 \mathrm{a}$ & $0.98 \pm 0.09 \mathrm{a}$ \\
\hline & Ultras & $1.39 \pm 0.23 b$ & $0.26 \pm 0.06 \mathrm{ab}$ & $1.44 \pm 0.04 \mathrm{c}$ \\
\hline & Mwave & $0.93 \pm 0.14 \mathrm{a}$ & $0.54 \pm 0.14 b c$ & $0.93 \pm 0.10 \mathrm{a}$ \\
\hline & Extrusion & $1.12 \pm 0.02 \mathrm{ab}$ & $0.77 \pm 0.10 \mathrm{c}$ & $1.21 \pm 0.04 b$ \\
\hline
\end{tabular}

The values are expressed as mean \pm Standard Deviation. There is no significant difference between means (within the same property and the same section of digestive tract) designated by the same letter at $\mathrm{P}<0.05$

At $\mathrm{pH}$ 6.6 Microwave treated DRBDF showed significant $(\mathrm{p} \leq 0.05)$ greater $\mathrm{WBC}$ compared to untreated. While micronization and ultrasonic treated DRBDF had the lowest WBC, whereas, WBC of extrusion, and untreated DRBDF, was similar.

In stomach condition ( $\mathrm{pH}$ 1.8) WBC of all DRBDF except those of ultrasonic treatment presented lower WBC compared to those in the oral cavity $(\mathrm{pH} 6.6)$. At $\mathrm{pH} 1.8 \mathrm{WBC}$ of Extrusion, microwave and micronization treated DRBDF were not significantly ( $\mathrm{p} \geq 0.05)$ different from each other but WBC of ultrasonic treated DRBDF was significantly $(\mathrm{p} \leq 0.05)$ higher followed by those of untreated DRBDF.

In the duodenum ( $\mathrm{pH}$ 8.7) the WBC of all DRBDF were higher than those from other cavities (oral cavity and stomach). However, WBC of extrusion and microwave treated DRBDF were not significantly different $(4.68 \mathrm{~g} / \mathrm{g}$ and $4.78 \mathrm{~g} / \mathrm{g}$ respectively) but they were significantly $(\mathrm{p}<0.05)$ greater than others (micronized fiber, ultrasonic treated, and untreated fibers). 
The lowest WBC of micronization and ultrasonic treated DRBDF and the highest WBC of microwave, extrusion treated and untreated DRBDF at pH 6.6 might be explained by their particle sizes. The particle sizes of these DRBDF are $133 \mu \mathrm{m}$ and $195 \mu \mathrm{m}$ respectively which are smaller than $550 \mu \mathrm{m}$. The reduction of particle sizes beyond $550 \mu \mathrm{m}$ may damage the DRBDF matrix and the collapse of the pore during these treatments, and decreased the hydration properties of these DRBDF (Auffret, Ralet, Guillon, Barry, \& Thibault, 1994; Sangnark \& Noomhorm, 2004). The relatively large sizes for microwave, extrusion treated and untreated DRBDF (475, 700 and 685 respectively) might be explained their higher WBC (Auffret, Ralet, Guillon, Barry, \& Thibault, 1994; Sangnark \& Noomhorm 2004).

On the other hand, microwave treatment was reported to have broken the weak bonds that existed in polysaccharide chains and rip apart glycosidic linkages in the DRBDF polysaccharides (Nyman \& Nilsson, 1994). The consequence could lead to a modification of the matrix its architecture and caused insoluble fiber to solubilized (Björck, Nyman, \& ASP, 1984). Moreover, during extrusion DRBDF was heated under pressure, shear and extruded through fine pores, which might open the DRBDF structure and let the free hydroxyl group from cellulose available to bind water (Sangnark \& Noomhorm, 2004). Collapse of the matrix structure due to increase in the theoretical surface area and total pore volume, thus the increase in hydration properties (Cadden, 1987).

The low WBC in acidic $\mathrm{pH}$ (pH1.8, stomach) might be due to partially soluble DRBDF. Soluble fibers are usually made up pectin and soluble hemicellulose. These components could bind more water in acidic $\mathrm{pH}$ (Prachi \& Premavalli, 2011).

The high WBC of all DRBDF in alkaline $\mathrm{pH}$ (pH 8.7, duodenum) revealed that these fibers have higher insoluble fibers component such as cellulose, which could bind more water at alkaline $\mathrm{pH}$ (Prachi \& Premavalli, 2011). Similar conclusions have been reported by Prachi \& Premavalli (2011) who studied the effect of particle size and $\mathrm{pH}$ on WBC in the pea peel and cardamom fiber containing higher insoluble dietary fiber component similar to those studied by Gorecka, Lampart-Szczapa, Janitz, \& Sokolowska (2000) results. Considering the results achieved in the present study, it can be assumed that microwave and extrusion treatments of dietary fiber improve its $\mathrm{WBC}$ at neutral and alkaline $\mathrm{pH}$ while, ultrasonic treatment improve it at acid $\mathrm{pH}$.

Swelling capacity tends to set the volume occupied by the fiber in hydrated state in gastrointestinal tract and is the function of the chemical composition and the physical structure of fiber matrix (Izydorczyk, Chornick, Paulley, Edward, \& Dexter, 2008). The results of SWC are shown in Table 2. These results revealed that the extruded and untreated DRBDF having large particle sizes (700 and $685 \mu \mathrm{m}$ respectively) exhibit a significant $(\mathrm{p} \leq 0.05)$ higher $\mathrm{SWC}$ at neutral $\mathrm{pH}(2.51 \mathrm{ml} / \mathrm{g}$ and $2.64 \mathrm{ml} / \mathrm{g}$ respectively) and in the alkaline $\mathrm{pH}(3.66 \mathrm{ml} / \mathrm{g}$ and $3.49 \mathrm{ml} / \mathrm{g}$ respectively) as compared to others treated DRBDF with small particles. Micronization and ultrasonic treatments significantly decreased the particle size consequently leading to the destruction of fiber matrix and low SWC, Sangnark \& Noomhorm (2004), and Prachi \& Premavalli (2011). All these DRBDF showed lower SWC in acidic pH i.e., 1.8, as compared to alkaline or neutral $\mathrm{pH}$ (Table 2). This SWC behavior of these DRBDF could be explained by the same reasons as well as in the case of WBC. Amongst the treated DRBDF, the highest SWC $(3.66 \mathrm{ml} / \mathrm{g})$ corresponded to extrusion treated DRBDF in duodenal condition $(\mathrm{pH} 8.7$ and incubation time $60 \mathrm{~min}$ ), while the lowest was obtained with microwave and ultrasonic treated DRBDF $(1.36 \mathrm{ml} / \mathrm{g})$ in stomach condition ( $\mathrm{pH} 1.8$, incubation time $135 \mathrm{~min})$. Therefore, the properties of the DRBDF could be modified by virtue of the duodenal alkalinization, the gastric acidification as well as the exposure to ionic constituents of the gut as reported in previous investigation (Gourgue, Champ, Guillon, \& Laval, 1994). The physical treatment seemed to be responsible for the difference observed in swelling capacity of the DRBDF based on the reasoning that such treatment might have changed the physical structure of fibre matrix.

Therefore, the physical treatments reduced the particle size which altered the physical structure resulting in the differential water imbibitions capacity.

In view of the present results, extrusion and microwave cooking treatment improved significantly WBC and SWC of DRBDF at neutral and alkaline $\mathrm{pH}$, while at acidic $\mathrm{pH}$ there were no significant improvements. In conclusion, WBC and SWC are dependent on the physical treatment, particle size as well as on pH.

\subsection{Effect of Physical Treatments and pH on Cation Exchange Capacity (CEC)}

Reduction in the bioavailability of minerals and trace elements to the body from gastro intestinal tract has been identified as a major setback associated with increased intake of dietary fiber (Mongeau, 2003). One mechanism by which dietary fiber may influence mineral availability is through cation exchange, which measures the ability of the fiber matrix to bind and hold ions on its surface. According to table 2, the CEC increased with decrease in acidity. Increasing pH from 1.8 to 8.7 increased the CEC of the DRBDF. Similar results were found by Prachi \& 
Premavalli (2011), where amongst radish ashgourd pea peel and cardamom peel fibers, highest CEC was found at $\mathrm{pH} 8.7$ (duodenal), while the lowest one at $\mathrm{pH} 1.8$ (stomach). Goreka, Lampart-Szczapa, Janitz, \& Sokolowska (2000) also reported the same conclusion with legume fibers. On other hand Torre, Rodriguez, \& Saura-Calixto (1992), reported that the mineral binding capacity of the fiber components increased with increase in $\mathrm{pH}$ and this can be attributed to the increase in ionization functional groups of these polymers with increasing $\mathrm{pH}$. Under alkaline $\mathrm{pH}$ conditions ( $\mathrm{pH} 8.7)$ ultrasonicated DRBDF $(1.44 \mathrm{meq} / \mathrm{g})$ showed higher CEC followed by extruded fibers $(1.21 \mathrm{meq} / \mathrm{g})$, untreated DRBDF $(1.20 \mathrm{meq} / \mathrm{g})$, micronized fibre $(0.98 \mathrm{meq} / \mathrm{g})$ and microwaved fibre $(0.93 \mathrm{meq} / \mathrm{g})$ (Table 2), while the lowest was observed under acid $\mathrm{pH}$ conditions $(\mathrm{pH} 1.8)$ with micronization treated DRBDF $(0.15 \mathrm{meq} / \mathrm{g})$. Thus, the physical treatments and the change in $\mathrm{pH}$ changed the degree of ionization of constituent in the matrix.

These results revealed that CEC as well as WBC and SWC, are related with $\mathrm{pH}$ and physical change in fibre matrix. Moreover, micronization treatment, which reduced significantly particle sizes, has also significantly lowered CEC of DRBDF at both alkaline and acidic $\mathrm{pH}$.

\subsection{Glucose Dialysis Retardation Index (GDRI)}

GDRI is a useful in vitro method to predict the effect of fiber on the delay of glucose adsorption in the gastrointestinal tract (Adiotomre, Eastwood, Edwards, \& Brydon, 1990). The GDRI of the physically modified DRBDF is shown in Figure 2; it was greater after $30 \mathrm{~min}$ than $60 \mathrm{~min}$ in all modified and untreated DRBDF. After $30 \mathrm{~min}$, the extruded DRBDF showed higher GDRI (40.73\%) followed by microwave treated, untreated and micronized DRBDF $(32.25 \%, 23.52 \%, 23.07 \%$ respectively) while ultrasoniced DRBDF exhibited the lowest GDRI (19.61\%). However, after 60min the GDRI of untreated and extruded DRBDF changed significantly ( $23.52 \%$ vs. $7.19 \%$ and 40.73 vs. $20.90 \%)$ than other treated DRBDF, which showed $16.45 \%$, $12.16 \%$ and $15.02 \%$ respectively for micronization, ultrasonic and microwave treated DRBDF. This sudden change in GDRI of untreated and extruded DRBDF may be due $t$ o their large particle sizes which hydrated rapidly. At initially stage they delayed glucose diffusion across the dialysis membrane as well as other treated DRBDF and as the time increased from 30min to $60 \mathrm{~min}$ they reached complete imbibitions and saturation, thus further retention of glucose did not occur (Prachi \& Premavalli, 2011). Moreover the GDRI decreased proportionally with the decrease of the DRBDF viscosity, thus, the extruded DRBDF having high viscosity $(27.24 \mathrm{mPa} . \mathrm{s}$ at $7 \% \mathrm{w} / \mathrm{v})$ exhibited the highest GDRI after $30 \mathrm{~min}$ and $60 \mathrm{~min}(40.73 \%$ and $20.90 \%$ respectively), while untreated DRBDF showed the lowest GDRI after 60min (7.19\%). Adiotomre, Eastwood, Edwards, \& Brydon, (1990) reported that the delay in glucose adsorption in the gastrointestinal tract could be mainly due to the fibres viscosity. The GDRI of the modified DRBDF were higher than values reported for wheat bran (Adiotomre, Eastwood, Edwards, \& Brydon 1990), guar gum, apple pectin, mango peel, lemon peel and carambola pomace (Chau, Huang, \& Lin, 2004), and Mangifera pajang fiber (Sadeq et al., 2011). This may be due to the fiber structure change which can affect their hydration properties and viscosity. Thus, the physical modification of DRBDF in general and extrusion treatment of DRBDF in particular delayed glucose diffusion and may help in control of postprandial blood glucose as a low calorie ingredient for fiber enrichment.

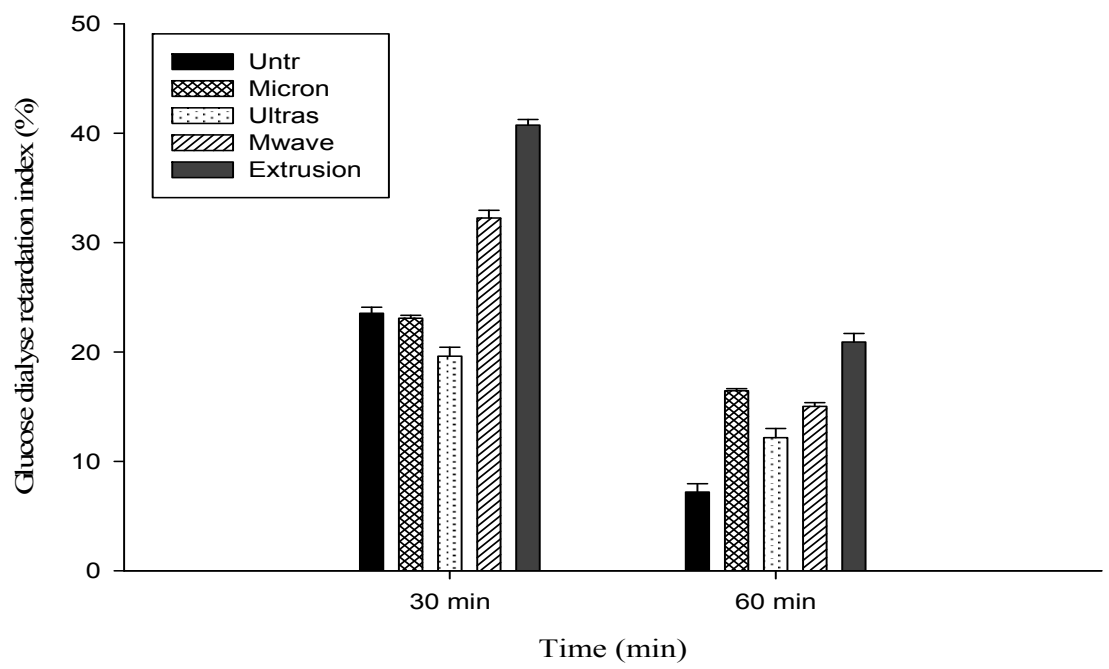

Figure 2. Glucose Dialysis Retardation Index (GRDI) physical modify dietary fibres (PMDF) derived from defatted rice bran 


\subsection{Effect of Physical Modifies Dietary Fiber on Glucose Diffusion in a Glucose-dietary Fiber System}

Glucose diffusion and glucose adsorption capacity are important parameters to measure the functionality of a fiber matter. The dialysis experiments mimic events occuring along the gastro intestinal tract. It is important to mention that the movement of glucose across the dialysis membrane in the experimental system cannot be true reflection of diffusion that occur in in vivo models. It only acted as a convective activity of the intestinal contraction in- vivo where the stirring could mimic the biological system more closely than an unstirred system (Prachi \& Premavalli, 2011). The experiment was carried out to assess the relative effects of untreated and physically modified DRBDF to inhibit glucose movement and to evaluate the action of physically modified DRBDF in lowering the postprandial serum glucose level. Figure 3 showed glucose diffusion rates which varied with different physical treatments. At initial time (30 and $60 \mathrm{~min})$, extrusion and micronization treated DRBDF diffused out significantly ( $\mathrm{p} \leq 0.05)$ low glucose amount (5602 to $7646 \mu \mathrm{mol}$ and 6053 to $9006 \mu \mathrm{mol}$ respectively) compared to untreated DRBDF (6922 to $9200 \mu \mathrm{mol})$, where the control ranged from 8093 to $12903 \mu \mathrm{mol}$. However, microwave and ultrasonic treated DRBDF exhibited significantly $(\mathrm{p} \leq 0.05)$ higher glucose diffusion rates ( 7305 to $9689 \mu \mathrm{mol}$ and 7369 to $10732 \mu \mathrm{mol})$.

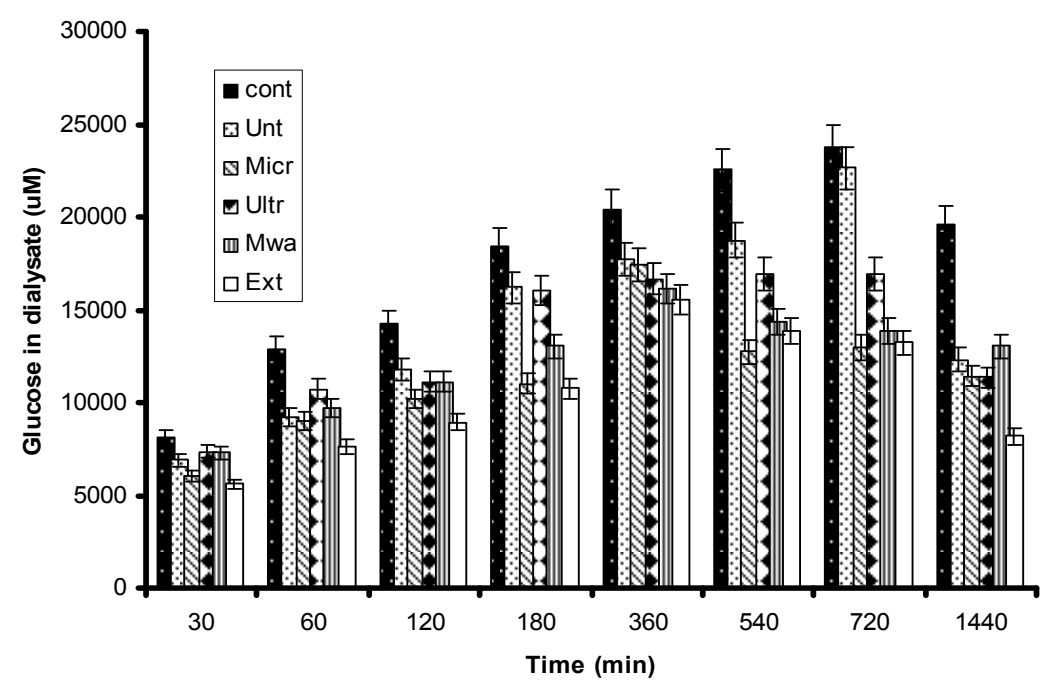

Figure 3. The glucose diffusion Assay in Physical Modify Dietary Fibres (PMDF) derived from defatted rice bran

Extrusion treated DRBDF showed significantly $(\mathrm{p} \leq 0.05)$ high retarding effect on the flow of glucose diffusion across the dialysis membrane for 6 hours. Similar trend was observed in microwave treated DRBDF. The amount of glucose diffused in the dialysate gradually increased to maximum levels in extruded and microwave treated DRBDF, (15522 and $16160 \mu \mathrm{mol}$ respectively) after 6 hours compared to control $(20439 \mu \mathrm{mol})$ and untreated DRBDF $(17757 \mu \mathrm{mol})$ where the maximum was reached after 12hours $(22631 \mu \mathrm{mol})$.

After 6 hours, the glucose level in the extrusion and microwave dialysates treated DRBDF decreased, this may be due to the equilibrium attained by the system. However micronization and ultrasonic treated DRBDF retarded

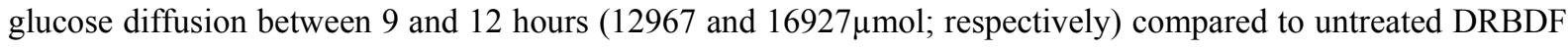
and control (22631 and $23738 \mu \mathrm{mol}$; respectively).

All DRBDF gave maximum glucose amount in their dialysates after 12 hours and it decreased afterward due to the equilibrium in the system. The glucose diffusion rate in all samples were faster at the initial stage which may be due to cereal bran high insoluble fibers content. Insoluble fibers hindered the diffusion of glucose, due to their glucose adsorption ability and entrapment within the fiber network. But, they become rapidly satured and imbibed, thus further retention of glucose is inhibited and the diffusion rate increased. Prachi \& Premavalli (2011) have reported that pea peel fibers and cardamom peel fibers could significantly $(p \leq 0.05)$ retarded the glucose diffusion only for 3hours after that the rate of glucose diffusion across dialysis membrane increased almost similar to control due to the insoluble fiber component in pea and cardamom. Chau, Huang, \& Lee (2003) revealed that the insoluble fiber densed portions could adsorb glucose, and impede its diffusion, thereby postponing the glucose adsorption in the GIT. Moreover extrusion treated DRBDF significantly slowed glucose 
diffusion $(10753 \mu \mathrm{mol}$ after 3 hours $)$ followed by micronization, microwave and ultrasonic treated fibres(11009, 13031 and $16054 \mu \mathrm{mol}$; respectively) compared to untreated DRBDF $(16203 \mu \mathrm{mol})$. This might be due to their higher viscosity compared to untreated. The delay in glucose adsorption in the GIT is mainly linked to the viscosity of polysaccharides (Adiotomre, Eastwood, Edwards, \& Brydon, 1990).

Thus, the physical treatments of DRBDF particulary extrusion treatment could improve the retardation of the glucose diffusion rate across the dialysis membrane, and retard its adsorption in the gastro intestinal tract which is usefull for blood glucose level regulation.

\subsection{Effect of Physical Treatments on the Glucose Adsorption Capacity (GAC) of Dietary Fiber}

Dietary fiber could act as functional dietary supplements for decreasing the rate of glucose adsorption as well as concentration of serum glucose when it can effectively absorb glucose (Yeh, Su, \& Lee, 2005). Figure 4 showed that amongst the four physically modified DRBDF, extrusion treated DRBDF could significantly $(\mathrm{p} \leq 0.05)$ adsorb maximum glucose $(4161 \mu \mathrm{mol} / \mathrm{g})$ followed by microwave, ultrasonic and micronization treated DRBDF (3892, 3834 and $3752 \mu \mathrm{mol} / \mathrm{g}$; respectively) compared to untreated DRBDF $(2758 \mu \mathrm{mol} / \mathrm{g})$. The highest glucose adsorption capacity of extruded DRBDF may be due to its large particle sizes and high viscosity. This could enhance the entrapment of glucose within the fibre matrix and minimize mobility of water on the surface and consequently increased hydration ability of large particles which contributed to the glucose rention on the fiber surface (Lopez et al., 1996). Viscosity favored gel formation which might improve glucose entrapment and hydration properties. Untreated DRBDF having large particle sizes showed low adsorption capacty, this could be due to the low viscosity. Thus, as time increased, the fibre attained saturation and could not contribute towards the increase in viscosity and as consequence it release the glucose from its network (Prach \& Premavalli, 2011). therefore, the physically modified DRBDF improved glucose adsorption capacity as well as reduced the glucose breakdown rate, thus shunning away an excess glucose in the body.

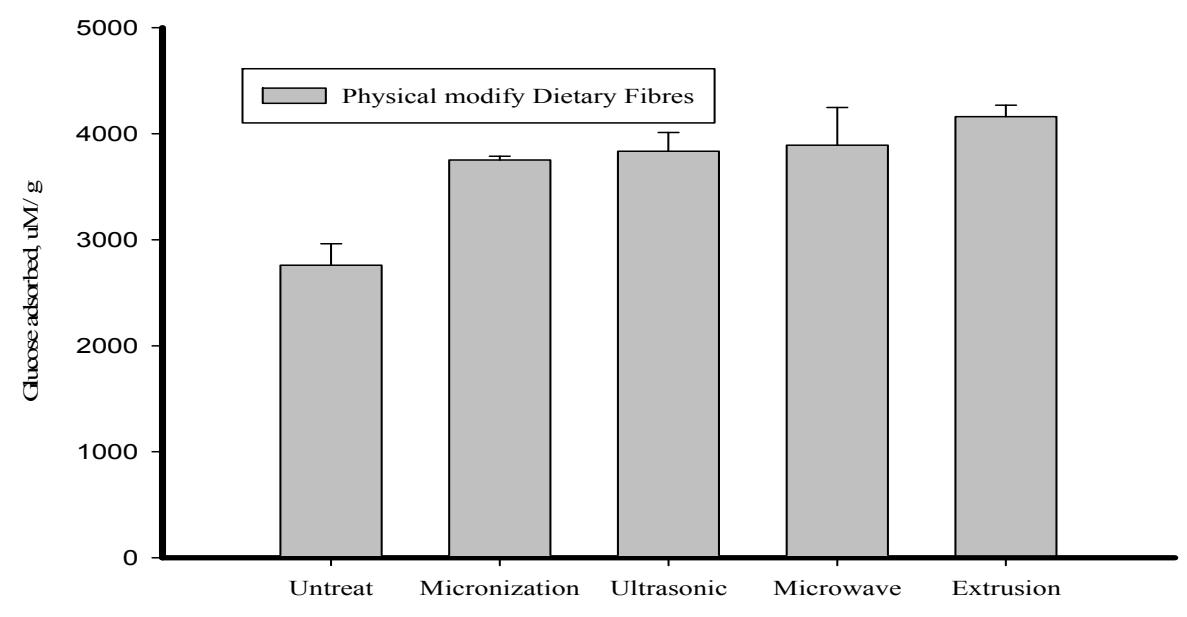

Figure 4. Glucose Adsorption Capacity (GAC) of Physical Modify Dietary Fibres (PMDF) derived from defatted rice bran

\section{Conclusion}

This study showed that physical modifications of DRBDF could improve its functional properties. Micronization, microwave and ultrasonic treatments significantly improved solubility, while extrusion treatment enhanced viscosity. Extrusion and microwave cooking treatments significantly increased WBC and SWC at oral and duodenum condition, but all treatments, except ultrasonic and extrusion treatments, showed minor effects on hydration properties at stomach condition. Thus, modified DRBDF might bind more water in duodenum and stomach condition which could help in fecal bulking, improved viscosity in the stomach and impede the gastric emptying.

The Physical modifications as well as the $\mathrm{pH}$ and time affected the CEC of DRBDF. Micronization treatment decreased significantly the CEC in stomach and duodenum conditions.

The extrusion treatment increased significantly GRDI and GAC. 
In view of obtained results the study confirmed that physically modified DRBDF especially extruded fibers have reduction effect on glucose breakdown rate and adsorption and thus can avoid increase in postprandial blood glucose level. However, these results should be confirmed by future in vitro animal studies.

Therefore, DRBDF might be incorporated in high-fibre foods as low calorie bulk ingredient for functional ingredient and hypoglycemic effect.

\section{References}

Adiotomre, J., Eastwood, M. C., Edwards, C. A., \& Brydon, W. G. (1990). Dietary fiber: in-vitro methods that anticipate nutrition and metabolic activity in humans. The American Journal of Clinical Nutrition, 52(1), 128-134. www.ajcn.org/content/52/1/128.full.pdf + html

Ang, J. F. (1991). Water retention capacity and viscosity effect of powdered cellulose. Journal of Food Science, 56(6), 1682-1684. http://dx.doi.org/10.1111/j.1365-2621.1991.tb08670.x

Auffret, A., Ralet, M. C., Guillon, F., Barry, J. L., \& Thibault, J. F. (1994). Effect of grinding and experimental conditions on the measurement of hydration properties of dietary fibres. Lebensmittel-Wissenschaft und Technologie, 27, 166-172. http://dx.doi.org/10.1006/fstl.1994.1033

Björck, I., Nyman, M., \& ASP, N. G. (1984).Extrusion cooking and dietary fibre: Effects on dietary fibres content and on degradation in rat intestinal tract. Cereal Chemistry, 61(2), 174-179. http://www.aaccnet.org/publications/cc/backissues/1984/Documents/chem61_174.pdf

Branen, A. L., Davidson, P. M., \& Salminen, S. (1990). Food additives, 1st Ed. New York: Marcel Dekker.

Cadden, S. M. (1987). Comparative effects of particle size reduction on physical structure and water binding properties of several plant fibres. Journal of Food Science, 52, 1595-1599. http://dx.doi.org/10.1111/j.1365-2621.1987.tb05886.x

Chau, C. F., Wang, Y. T., \& Wen, Y. L. (2007). Different micronization methods significantly improve the functionality of carrot insoluble fiber. Food Chemistry, 100, 1402-1408. http://dx.doi.org/10.1016/j.foodchem.2005.11.034

Chau, C. F., Huang, Y. L., \& Lin, C. Y. (2004). Investigation of the cholesterol-lowering action of insoluble fibre derived from the peel of Citrus sinensis L. cv. Liucheng. Food Chemistry, 87(3), 361-366 http://dx.doi.org/10.1016/j.foodchem.2003.12.006

Chau, C. F., Huang, Y. L., \& Lee, M. H. (2003). In-vitro hypoglycemic effects of different insoluble fibre rich fractions prepared from the peel of Citrus Sinensis L cv. Liucheng. Journal of Agriculture and Food Chemistry, 51, 6623-6626. http://dx.doi.org/10.1021/jf034449y

Chen, X., Yang, X., \& Xu, Y. H. (2001). Dregs Preparation of dietary fiber port. Soybean Science, 20(2), 28-132. http://www.cqvip.com/qk/93167X/200101/

Chen, R. H., Chang., J. R., \& Shyur, J. S. (1997). Effects of ultrasonic conditions and storage in acidic solutions on changes in molecular weight and polydispersity of treated chitosan. Carbohydrate Research, 299, 287-294. http://dx.doi.org/10.1016/S0008-6215(97)00019-0

Chiun-C. R., W., Jhih-Ying, C., Po-Yuan, C. (2009). Effect of micronization on functional properties of the water caltrop (Trapa taiwanensis Nakai) pericarp. Food Chemistry, 113, 970-974. http://dx.doi.org/10.1016/j.foodchem.2008.08.048

Dietary Reference Intakes Proposed Definition of Dietary Fiber. (2001). A Report of the Panel on the Definition of Dietary Fiber and the Standing Committee on the Scientific Evaluation of Dietary Reference Intakes Food and Nutrition Board INSTITUTE OF MEDICINE NATIONAL ACADEMY PRESS Washington, D. C. p. 64.

Fleury, N., \& Lahaye, M. (1991). Chemical and physicochemical characteristics of fibres from Laminaria digitata (Kombu Breton): A Physiological approach. Journal of the Science of Food and Agriculture, 55, 389-400. http://dx.doi.org/10.1002/jsfa.2740550307

Frost, J., Hegedus, E. F., \& Glicksman, M. (1984). Objective characterization of hydrocolloid Organoleptic $\begin{array}{llll}\text { Properties. } & \text { Food Technology, } & \text { 38(1), }\end{array}$ http://agris.fao.org/agris-search/search/display.do?f=1985/US/US85136.xml;US8500039 
Gorecka, D., Lampart-Szczapa, E., Janitz, W., \& Sokolowska, B. (2000). Composition of fractional properties of dietary fibre of lupines (L.luteus and L. albus). Nahrung, 44(4), 229-232. http://dx.doi.org/10.1002/1521-3803 (20000701)44:4<229: AID-FOOD229>3.0.CO;2-I

Gourgue, C., Champ, M, Guillon, F., \& Laval, J. D. (1994) Effect of extrusion-cooking on the hypoglycemic properties of citrus fibre: An in vitro study. Journal of the Science of Food and Agriculture, 64, 493-499. http://dx.doi.org/10.1002/jsfa.2740640416

Izydorczyk, M. S., Chornick, T. L., Paulley, F. G., Edward, N. M., \& Dexter, J. E. (2008). Physico-chemical properties of hull-les barley fibre-rich fraction varying in particle size and their potential as functional ingredients in two-layer flat bread. Food Chemistry, 108, 561-570. http://dx.doi.org/10.1016/j.foodchem.2007.11.012

Lewandowicz, G., Formal, J., \& Walkowski, A. (1997). Effect of microwave radiation on physico-chemical properties and structure of potato and tapioca starches. Carbohydrate Polymers, 34, 213-230. http://dx.doi.org/10.1016/S0144-8617(97)00091-X

Lopez, G., Ros, G., Rincon, F., Periago, M. J., Martinez, M. C., \& Ortuño, J. (1996). Relationship between physical and hydration properties of soluble and insoluble fiber of Artichoke. Journal Agriculture and Food Chemistry, 44, 2773-2778. http://dx.doi.org/10.1021/jf9507699

Mongeau, R.., \& Brooks, P. J. (2003) Properties, sources and determination. In 2nd ed. Caballero, B, Turgo, L. Z., Finglas, P. M., eds. Encyclopedia of Food Science and Nutrition(Vol. 3, pp. 1813-1832), Academic Press. http://dx.doi.org/10.1016/B0-12-227055-X/00342-4

Nyman, M., \& Nilsson, T. (1994). Effect of long-term storage on dietary fibre in different cultivars of carrots. Acta Agriculturae Scandinavica Sect. B, Soil Plant Science, 44, 116-122. http://dx.doi.org/10.1080/09064719409414912

O’Dea, K., Nestel, P. J., \& Antonoff, L. (1980). Physical factors influencing postprandial glucose and insulin response to starch. American Journal of Clinical Nutrition, 33, 760. http://www.ajen.org/content/33/4/760.full.pdf

Ogawa, S., Decker, E. A., \& Mc Clements, D. J. (2003). Production and characterization of o/w emulsions containing cationic droplets stabilized by lecithin-chitosan membranes. Journal of Agricultural and Food Chemistry, 51, 2806-2812. http://dx.doi.org/10.1021/jf020590f

Ou, S., Kwok, K., Li, Y., \& Fu, L. (2001). In-vitro study of possible role of dietary fiber in lowering postprandial serum glucose. Journal of Agriculture and Food Chemistry, 49, 1026-1029. http://dx.doi.org/10.1021/jf000574n

Prachi, G., \& Premavalli, K. S. (2011). In-vitro studies on functional properties of selected natural dietary fibers. International journal of food properties, 14, 397-410. http://dx.doi.org/10.1080/10942910903207736

Prakongpan, T., Nitithamyong A., \& Luangpituksa, P. (2002). Extraction and Application of Dietary Fiber and Cellulose from Pineapple Cores. Journal of food science, 67(4), 1308-1313. http://onlinelibrary.wiley.com/doi/10.1111/j.1365-2621.2002.tb10279.x/pdf

Robertson, J. A., \& Eastwood, M. A. (1981). An examination of factors, which may affect the water holding capacity of dietary fibre. British Journal of Nutrition, 45, 83-88. http://dx.doi.org/10.1079/BJN19810079

Sadeq, H. A., Amin, I., Mohd, Y. M., Shuhaimi, M., Rokiah, M. Y., \& Fouad, A. H. (2011). Functional Properties and Characterization of dietary fiber from Mangifera pajang Kort. Fruit pulp. Journal of Agricultural and Food chemistry, 59, 3980-3985. http://dx.doi.org/10.1021/jf103956g

Sangnark, A., \& Noomhorm, A. (2004). Effect of dietary fibre from sugarcane bagasse and sucrose esteron dough and bread properties. Lebensmittel-Wissenschaft und Technologie, 37, 697-704. http://dx.doi.org/10.1016/j.1wt.2004.02.015

Schneeman, B. O. (1998). Dietary fibre and GI function. Nutrition Research, 18, 625-632. http://dx.doi.org/10.1002/9780470999615.ch14

Shengdong, Z., Ziniu, Y., Yuanxin, W., Xia, Z., Hui, L., \& Ming, G. (2005). Enhancing enzymatic hydrolysis of rice straw by microwave pretreatment. Chemical Engineering Communications, 192, 1559-1566. http://dx.doi.org/10.1080/009864491007750 
Sowbhagya, H. B., Florence, S. P., Mahadevamma, S., \& Taranathan, R. N. (2007). Spent residue from cumin - a potential source of dietary fibre. Food Chemistry, 104, 1220-1225. http://dx.doi.org/10.1016/j.foodchem.2007.01.066

Sreenath, H. K., Katsambis, R., Sudarshanakrishna, Prasad, N. N., \& Santhanam, K. (1996) Characteristics of some fibre incorporated cake preparations and their dietary fibre content. Starch/Starke, 48(2), 72-76. http://dx.doi.org/10.1002/star.19960480208

Özlem, T. (2009). Effect of Cooking Methods on Dietary Fibre Components of Fresh Vegetables, Legume and Cereal Samples. Kahramanmaras Sutcu Imam University Journal of Natural Sciences, 12(2), 17-20. http://dergi.ksu.edu.tr/public/journals/2/backIssues/sayi/12/122pdf/122_17_20.pdf

Torre, M., Rodriguez, A. R., \& Saura-Calixto, F. (1992). Study of the interactions of calcium ions with lignin. Journal of Agriculture and Food Chemistry, 40, 1762-1766. http://dx.doi.org/10.1021/jf00022a007

Valiente, C., Molla, E., Martin-Cabrejas, M. M., Lopez-Andreu, F. J., \& Esteban, R. M. (1996). Cadmium binding capacity of cocoa and isolated total dietary fibre under physiological $\mathrm{pH}$ conditions. Journal of the $\begin{array}{lllll}\text { Science of } \quad \text { Food } & \text { Agriculture, } & 72, & 476-482 .\end{array}$ http://dx.doi.org/10.1002/(SICI)1097-0010(199612)72:4<476: AID-JSFA682>3.0.CO; 2-M

Varo, P., Laine, R., \& Koivistoinen, P. (1983). Effect of heat treatment on dietary fibre: interlaboratory study. Journal of Association Official Analytical Chemist, 66, 933. http://www.ncbi.nlm.nih.gov/pubmed/6309732

Yeh, H. Y., Su, N. W., \& Lee, M. H. (2005). Chemical compositions and physico-chemical properties of the fiber-rich materials prepared from Shoyu mash residue. Journal of Agriculture and Food Chemistry, 53, 4361-4366. http://dx.doi.org/10.1021/jf050243g

Zhu, S. D., Wu, Y. X., Yu, Z. N., Chen, Q. M., Wu, G. Y., Yu, F. Q., et al. (2006). Microwave assisted alkali pre-treatment of wheat straw and its enzymatic hydrolysis. Biosystems Engineering, 94(3), 437-442. http://dx.doi.org/10.1016/j.biosystemseng.2006.04.002 